ARTIKEL

\title{
PENTINGNYA KEPEMIMPINAN DAN KOMPETENSI DALAM MENINGKATKAN KINERJA PENGADAAN BARANG DAN JASA PEMERINTAH
}

\author{
Surya Pujoyono ${ }^{1}$, Bahrullah Akbar ${ }^{2}$, Aries Djaenuri ${ }^{3}$, Muh. Ilham ${ }^{4}$ \\ ${ }^{1,2,3,4}$ Institut Pemerintahan Dalam Negeri (IPDN) \\ Email: surya.pujoyono@ipdn.ac.id
}

\begin{abstract}
Abstrak
Penelitian ini bertujuan untuk menganalisis pengaruh kepemimpinan dan kompetensi terhadap kinerja pengadaan barang dan jasa pemerintah di Direktorat Pencegahan dan Pengendalian Penyakit Menular Langsung Kementerian Kesehatan Republik Indonesia. Penelitian ini menggunakan pendekatan kuantitatif. Pengumpulan data dilakukan menggunakan membagikan kuesioner kepada 104 responden yang diambil secara sensus. Analisis data dilakukan dengan menggunakan SPSS. Hasil penelitian menemukan bahwa kepemimpinan dan kompetensi berpengaruh terhadap kinerja pengadaan barang dan jasa pemerintah di Direktorat Pencegahan dan Pengendalian Penyakit Menular Langsung Kementerian Kesehatan Republik Indonesia, baik secara parsial maupun secara simultan.
\end{abstract}

Kata Kunci: Kepemimpinan, Kompetensi, Kinerja, Pengadaan Barang dan Jasa Pemerintah.

\begin{abstract}
This study aims to analyze the influence of leadership and competence on the performance of government procurement of goods and services in the Directorate of Prevention and Control of Direct Communicable Diseases of the Ministry of Health of the Republic of Indonesia. This study uses a quantitative approach. Data collection was carried out using questionnaires to 104 respondents taken by census. Data analysis was performed using SPSS. The results found that leadership and competence affect the performance of government procurement of goods and services in the Directorate of Prevention and Control of Direct Communicable Diseases of the Ministry of Health of the Republic of Indonesia, both partially and simultaneously.
\end{abstract}

Keywords: Leadership, Competence, Performance, Procurement of Government Goods and Services.

\section{A. PENDAHULUAN}

Pengadaan barang / jasa pemerintah di Kementerian Kesehatan Republik Indonesia secara elektronik dilakukan oleh penyelenggara yang terdiri dari unsur-unsur LPSE, PPK, Panitia Pengadaan dan Penyedia Barang/Jasa. LPSE, PPK, Panitia Pengadaan, dan Penyedia Barang/Layanan yang tersedia secara hukum: kerahasiaan dan penyalahgunaan kode akses (ID Pengguna dan Kata Sandi) dalam pengoperasian barang/ layanan elektronik; kerahasiaan dan 


\section{ARTIKEL}

penyalahgunaan data dan informasi elektronik yang tidak dimaksudkan untuk penggunaan publik; memenuhi ketentuan yang berlaku dalam pengadaan barang/jasa. LPSE, PPK, Panitia Pengadaan, dan Penyedia Barang/Jasa dilarang: mengganggu, dan/atau merusak sistem pengadaan barang/jasa secara elektronik; mencuri informasi, memanipulasi data, dan/atau menipu dalam pengadaan barang/jasa secara elektronik yang dapat mempengaruhi tujuan pengadaan. Selain memenuhi ketentuan sebagaimana dimaksud, LPSE, PPK, Komite Pengadaan dan Penyedia Barang/Jasa harus mematuhi etika pengadaan barang/jasa sebagaimana diatur dalam undang-undang.

Pengadaan barang / jasa di lingkungan Direktorat P2PML tampaknya menjadi fenomena kinerja birokrasi yang tidak dapat dipisahkan dari pengaruh berbagai variabel. Fenomena yang dimaksud adalah gejala, peristiwa, peristiwa atau keadaan tertentu yang terjadi dalam proses implementasi kebijakan dan kegiatan dalam pengadaan barang dan jasa di sektor kesehatan. Dampak dari fenomena ini tentu tidak terbatas pada lingkungan internal direktorat saja. Lingkungan eksternal atau masyarakat juga dapat dipengaruhi oleh fenomena ini. Berkenaan dengan fenomena yang diambil dari masalah dan penyebabnya, diasumsikan bahwa kepemimpinan dan kompetensi memiliki pengaruh signifikan terhadap kinerja pengadaan barang dan jasa pemerintah. Asumsi ini didasarkan pada premis mayor dan minor berikut:

Kepemimpinan, merupakan proses interaksi sosial yang terjadi antara unsur-unsur kepemimpinan dan staf dalam melaksanakan kebijakan dan atau kegiatan Direktorat, berkorelasi secara dinamis dengan pandangan, sikap, dan perilaku aparatur dalam melaksanakan pekerjaan mereka. Penyebab masalah berupa kelemahan pejabat KPA dalam mengendalikan proses pengadaan barang dan jasa yang telah diungkapkan oleh BPK dapat diindikasikan sebagai variabel Kepemimpinan. Oleh karena itu, secara kondisional dan fungsional, Kepemimpinan tentu saja mempengaruhi Pengadaan Barang dan Jasa Pemerintah di Direktorat Pencegahan dan Pengendalian Penyakit Menular Langsung.

Kepemimpinan sebagai kemampuan untuk mempengaruhi suatu kelompok menuju pencapaian tujuan. Sumber pengaruh ini mungkin formal, seperti yang disediakan oleh kepemilikan pangkat manajerial dalam suatu organisasi. Karena posisi manajemen datang dengan beberapa tingkat otoritas yang ditunjuk secara formal, seseorang dapat mengambil peran kepemimpinan hanya karena posisi yang dipegangnya dalam organisasi. Tetapi tidak semua pemimpin adalah manajer; bukan untuk hal itu, semua pemimpin manajer. Hanya karena sebuah 


\section{ARTIKEL}

organisasi memberi para manajernya hak-hak formal tertentu, tidak ada jaminan bahwa mereka akan dapat memimpin secara efektif. Kami menemukan kepemimpinan nonsanctioned yaitu, kemampuan untuk mempengaruhi yang muncul di luar struktur formal organisasi sering lebih penting daripada pengaruh formal (Robbins, 1998).

Kompetensi, yang merupakan faktor internal aparatur yang meliputi kapasitas fisik, kapasitas intelektual, kualitas sikap mental dan kemampuan sosial yang diaktualisasikan ke dalam lingkungan kerja, berkorelasi secara dinamis dengan pandangan, sikap, dan perilaku aparatur dalam melaksanakan pekerjaan mereka . Penyebab masalah dalam bentuk perilaku tidak profesional dan tidak akurat dalam melakukan tugas pengadaan barang dan jasa yang telah diungkapkan oleh BPK dapat diindikasikan sebagai variabel Kompetensi. Oleh karena itu, secara kondisional, Kompetensi tentu saja mempengaruhi Pengadaan Barang dan Jasa Pemerintah di Direktorat Pencegahan dan Pengendalian Penyakit Menular Langsung.

Kompetensi memiliki dua makna yang relevan, yang pertama, membahas kemampuan individu untuk bekerja secara efektif di bidang yang relevan dengan pekerjaan. Yang kedua, adalah definisi tentang apa yang diperlukan seseorang, untuk kinerja yang efektif. Keduanya terkait erat tetapi berbeda. Arti kedua, melibatkan mendefinisikan apa yang penting untuk menjadi sukses dalam suatu pekerjaan, sedangkan yang pertama berkaitan dengan sejauh mana seseorang melakukannya, apa yang penting untuk suatu pekerjaan. Mendefinisikan kompetensi kerja berguna dalam membantu individu untuk mengembangkan kompetensi mereka untuk pekerjaan itu. Area ini terkait dengan kesuksesan dalam peran seorang pekerja. Berdasarkan definisi ini, model kompetensi adalah pengelompokan kompetensi individu, yang menggambarkan semua, atau sebagian besar persyaratan untuk fungsi pekerjaan, atau keberhasilan organisasi (Shermon, 2004).

Kepemimpinan dan kompetensi yang dianggap sebagai variabel yang memiliki pengaruh signifikan terhadap kinerja pengadaan barang dan jasa pemerintah diperkuat melalui penelitian oleh Siregar (2006), Kiage (2013), Keno (2017), Kurnia (2016), Ash'ary (2017)), Harwiki (2015) dan Tsai et al. (2015). Tujuan penelitian adalah untuk mengetahui pengaruh kepemimpinan dan kompetensi terhadap kinerja pengadaan barang dan jasa pemerintah di Direktorat Pencegahan dan Pengendalian Penyakit Menular Langsung Kementerian Kesehatan Republik Indonesia. 


\section{ARTIKEL}

\section{B. METODE PENELITIAN}

Penelitian ini menggunakan pendekatan kuantitatif (Creswell, 1994; Arikunto, 1998). Jumlah sampel dalam penelitian ini diambil secara sensus dari semua unsur pimpinan dan karyawan Direktorat Pencegahan dan Pengendalian Penyakit Infeksi Langsung Kementerian Kesehatan Republik Indonesia, berjumlah 104 (Sugiyono, 2009). Teknik pengumpulan data dilakukan dengan menggunakan pembagian kuesioner. Dari data yang diperoleh melalui kuesioner penelitian, pengolahan data dan analisis akan dilakukan sesuai dengan tujuan penelitian yang dinyatakan. Dalam penelitian ini, metode analisis yang digunakan adalah analisis kuantitatif dengan regresi linier berganda (Ghozali, 2008).

\section{HASIL DAN PEMBAHASAN}

1. Analisis Pengaruh Kepemimpinan Terhadap Kinerja Pengadaan Barang dan Jasa Pemerintah di Direktorat Pencegahan dan Pengendalian Penyakit Menular Langsung Kementerian Kesehatan Republik Indonesia.

Berdasarkan hasil uji statistik, dapat dilihat bahwa nilai t pengaruh kepemimpinan terhadap kinerja pengadaan barang dan jasa pemerintah di Direktorat P2PML Kementerian Kesehatan dalam penelitian ini adalah 2,065 dan 1,034, masing-masing. Nilai T-hitung 2,065 menunjukkan bahwa kepemimpinan terbukti secara empiris memiliki pengaruh yang signifikan terhadap Pengadaan Barang dan Jasa Pemerintah di Direktorat P2PML Kementerian Kesehatan. Hasil ini juga menunjukkan bahwa Kepemimpinan tidak memiliki hubungan kausal (sebab dan akibat) secara langsung dengan kinerja pengadaan barang dan jasa pemerintah di Direktorat P2PML Kementerian Kesehatan.

Berdasarkan hasil uji Confirmatory Factor Analysis (CFA), Direction Setter secara empiris terbukti menjadi dimensi analisis yang memiliki kontribusi tertinggi terhadap variabel laten Kepemimpinan. Namun, dengan melihat hasil pengolahan data yang menunjukkan bahwa variabel laten Kepemimpinan terbukti berpengaruh signifikan terhadap Pengadaan Barang dan Jasa Pemerintah pada Direktorat P2PML Kementerian Kesehatan, maka untuk meningkatkan kinerja pengadaan barang dan jasa pemerintah di Direktorat P2PML Kementerian Kesehatan tidak dapat dilakukan melalui peningkatan dimensi kualitas Direction Setter. 
ARTIKEL

\section{Analisis Pengaruh Kompetensi Terhadap Kinerja Pengadaan Barang dan Jasa Pemerintah di Direktorat Pencegahan dan Pengendalian Penyakit Menular Langsung Kementerian Kesehatan Republik Indonesia.}

Berdasarkan hasil uji statistik, dapat diketahui bahwa nilai-t dan koefisien jalur terhadap pengaruh Kompetensi terhadap Pengadaan Barang dan Jasa Pemerintah pada Direktorat P2PML Kementerian Kesehatan dalam penelitian ini adalah 4,664 dan 0,528, masing-masing. Nilai t 4,664 menunjukkan bahwa kompetensi telah dibuktikan secara empiris memiliki pengaruh signifikan terhadap kinerja Pengadaan Barang dan Jasa Pemerintah di Direktorat P2PML Kementerian Kesehatan. Sedangkan nilai koefisien jalur sebesar 0,528 menunjukkan bahwa pengaruhnya searah (positif) dan relatif kuat. Hasil penelitian juga menunjukkan bahwa kompetensi memiliki hubungan sebab akibat yang kuat dengan kinerja Pengadaan Barang dan Jasa Pemerintah di Direktorat P2PML Kementerian Kesehatan. Ini menunjukkan bahwa jika kualitas kompetensi ditingkatkan, hal itu tentu akan meningkatkan kinerja Pengadaan Barang dan Jasa Pemerintah di Direktorat P2PML Kementerian Kesehatan.

Oleh karena itu, kualitas Pengadaan Barang dan Jasa Pemerintah di Direktorat P2PML Kesehatan dapat ditingkatkan atau ditingkatkan dengan mengoptimalkan 5 (lima) dimensi yang terdiri dari 15 (lima belas) variabel manifes. Lima dimensi yang dapat dioptimalkan adalah motif, ciri, konsep-diri, pengetahuan, dan keterampilan. Sedangkan lima belas (15) variabel manifes yang dapat dioptimalkan adalah motivasi melayani, motivasi melayani, motivasi berprestasi, karakter, penampilan, sikap, perilaku, pengetahuan tentang administrasi kerja, pengetahuan tentang manajemen aktivitas, pengetahuan tentang pekerjaan teknis, keterampilan manajerial, teknis keterampilan, dan keterampilan sosial.

Berdasarkan hasil uji Confirmatory Factor Analysis (CFA), Self Concept secara empiris terbukti menjadi dimensi analitis yang memiliki kontribusi tertinggi terhadap variabel laten kompetensi. Oleh karena itu, untuk meningkatkan kualitas Pengadaan Barang dan Jasa Pemerintah di Direktorat P2PML Kementerian Kesehatan dapat dilakukan dengan menjadikan peningkatan kualitas dimensi Konsep Diri sebagai prioritas utama.

Dimensions of Self Concept terdiri dari 3 (tiga) variabel manifes, yaitu Self-display, Attitude, dan Behavior. Dari 3 (tiga) variabel manifes, Perilaku secara empiris memiliki kontribusi tertinggi. Jadi, berdasarkan hasil penelitian, dapat dikatakan bahwa untuk 


\section{ARTIKEL}

meningkatkan kinerja pengadaan barang dan jasa pemerintah, kualitas perilaku adalah prioritas utama yang harus ditingkatkan dibandingkan dengan 2 (dua) variabel manifes lainnya.

\section{Analisis Pengaruh Kepemimpinan dan Kompetensi Terhadap Kinerja Pengadaan Barang dan Jasa Pemerintah di Direktorat Pencegahan dan Pengendalian Penyakit Menular Langsung Kementerian Kesehatan Republik Indonesia.}

Hasil uji statistik menunjukkan bahwa kepemimpinan dan kompetensi terbukti secara empiris memiliki pengaruh yang signifikan terhadap kinerja pengadaan barang dan jasa pemerintah pada Direktorat P2PML Kementerian Kesehatan. Hasil penelitian menunjukkan bahwa kepemimpinan dan kompetensi memiliki hubungan sebab akibat yang kuat dengan kinerja pengadaan barang dan jasa pemerintah di Direktorat P2PML Kementerian Kesehatan. Ini menunjukkan bahwa jika kualitas kepemimpinan dan kompetensi ditingkatkan, hal itu tentu akan meningkatkan kinerja pengadaan barang dan jasa pemerintah pada Direktorat P2PML Kementerian Kesehatan Republik Indonesia.

Oleh karena itu, kinerja pengadaan barang dan jasa pemerintah di Direktorat P2PML Kementerian Kesehatan dapat ditingkatkan dan dioptimalkan dengan meningkatkan kepemimpinan dan kompetensi memalui 4 (empat) dimensi yang terdiri dari 12 (dua belas) variabel manifes kepemimpinan. Empat dimensi yang dapat dioptimalkan adalah Juru Bicara, Penentu Arah, Pelatih, dan Agen Perubahan. Sedangkan dua belas (12) variabel manifes yang dapat dioptimalkan adalah peran pemimpin sebagai juru bicara untuk pengambilan keputusan, peran pemimpin sebagai juru bicara kebijakan, peran pemimpin sebagai juru bicara kelembagaan, peran pemimpin sebagai regulator, peran pemimpin sebagai direktur, peran pemimpin sebagai pengontrol, peran pemimpin sebagai motivator, peran pemimpin sebagai fasilitator, peran pemimpin sebagai instruktur, peran pemimpin sebagai inovator dari perubahan, peran pemimpin sebagai kolaborator perubahan, dan peran pemimpin sebagai pelopor perubahan.

Kepemimpinan yang dipengaruhi oleh 4 (empat) dimensi dan 12 (dua belas) variabel manifes yang ada di Direktorat P2PML Kementerian Kesehatan harus berorientasi pada peningkatan kualitas kompetensi. Upaya ini dapat dilakukan dengan mengarahkan kepemimpinan meningkatkan, dan mengoptimalkan 5 (lima) dimensi yang terdiri dari 15 (lima belas) variabel manifes. Lima dimensi yang dapat dioptimalkan adalah motif, ciri, konsep-diri, pengetahuan, dan keterampilan. Sedangkan lima belas (15) variabel manifes yang dapat 
ARTIKEL

dioptimalkan adalah motivasi melayani, motivasi melayani, motivasi berprestasi, karakter, penampilan, sikap, perilaku, pengetahuan tentang administrasi kerja, pengetahuan tentang manajemen kegiatan, pengetahuan tentang pekerjaan teknis, keterampilan kerja manajerial, keterampilan teknis, dan keterampilan sosial.

\section{KESIMPULAN}

Berdasarkan hasil penelitian diketahui bahwa kepemimpinan dan kompetensi berpengaruh secara signfikan terhadap kinerja pengadaan barang dan jasa pemerintah di Direktorat Pencegahan dan Pengendalian Penyakit Menular Langsung Kementerian Kesehatan Republik Indonesia, baik secara parsial maupun secara simultan.

\section{DAFTAR PUSTAKA}

Arikunto, S. (1998). Prosedur Penelitian, Suatu Pendekatan Praktek. Jakarta: Rineka Cipta.

Creswel, J. W. (1994). Research Design Qualitative \& Quantitative Approaches. New Delhi: Sage Publication.

George, J. M., Jones, G. R., \& Sharbrough, W. C. (2005). Understanding and managing organizational behavior. Upper Saddle River, NJ: Pearson Prentice Hall.

Ghozali. I. (2008). Structural Equation Modeling Metode Alternatif dengan Partial Least Square $(P L S)$. Semarang: Badan Penerbit Universitas Diponegoro.

Harwiki, W. (2015). The Impact of Servant Leadership on Organization Culture, Organizational Commitment, Organizational Citizenship Behaviour (OCB) and Employee Performance in Women Cooperatives. Procedia-Social and Behavioral Sciences, 219, 283-290.

Keno, A. (2017). Determinants of Procurement Performance in Wolaita Sodo University: Customers` Perception. European Journal of Business and Management, 9(4).

Kiage, J. O. (2014). Factors Affecting Procurement Performance: A Case of Ministry of Energy. International Journal of Business and Commerce, 3(1), 54-70.

Robbins, S. P. (1998). Organizational Behavior Concepts Controversies Applications. New Jersey: Prentice-Hall International, Inc.

Shermon, G. (2004). Competency based HRM. India: McGraw-Hill Publishing Company Limited.

Sugiyono. (2005). Statistik Untuk Penelitian. Bandung: CV. Alfabeta.

Tsai, Y., Wang, H., \& Yuan, C. (2015). Transformational Leadership and Job Performance: The Case of SMEs in Taiwan. International Journal of Arts and Commerce, 4(8), 57-71. 